\title{
Decapod Crustaceans in the Marmara Island (Marmara Sea) and Ecological Characteristics of Their Habitats
}

\author{
Begum Ayfer, Husamettin Balkis, Aysegul Mulayim* \\ Istanbul University, Faculty of Science, Department of Biology, Istanbul, Turkey
}

Please cite this article as: Ayfer B, Balkis H, Mulayim A. Decapod Crustaceans in the Marmara Island (Marmara Sea) and Ecological Characteristics of Their Habitats. Eur J Biol 2017; 76(1): 20-5.

\begin{abstract}
We have performed series of analyses to identify decapod crustaceans inhabiting the littoral zone of the Marmara Island and to study specific ecological characteristics of the habitat. Samples of decapod crustaceans species were collected from 12 stations (6 onshore, 6 offshore) on May 12-17, 2008 and November 17-22, 2008. A total of 17 species and 1199 specimens of decapod crustaceans were recorded. Eigth species (A. lacazei, N. norvegicus, P. bluteli, P. longimana, P. platycheles, D. pugilator, $D$. personata and $L$. vernalis) have been reported in the littoral zone of Marmara Island for the first time in this study. Also our study also sheds light on some ecological properties (temperature, salinity, dissolved oxygen) of the habitats of the species from the littoral zone of the Marmara Island.
\end{abstract}

Keywords: Ecology, decapoda, crustacea, Marmara Island, The Sea of Marmara

\section{INTRODUCTION}

The Archipelago in the Sea of Marmara consisting of small and large islands located southwest of the Sea of Marmara and the northwest of the Kapıdağ Peninsula are referred to as the Islands of Marmara. With an area of $120 \mathrm{~km}^{2}$, the Marmara Island is the largest of these islands in the Sea of Marmara. The Marmara Island extends to $18 \mathrm{~km}$ in the east-west direction and has coastline of $10 \mathrm{~km}$ in the north-south. Deep-water pink shrimp and rock lobster are target species for commercial fishing activities in the area (1).

The Marmara Island has similar water characteristics to the Sea of Marmara; the upper water layer is the Black Sea and the lower water layer is the Mediterranean Sea. The Black Sea water (low salinity: 18) and the Mediterranean water (high salinity: 38) do not mix with each other due to different densities of salinity, but form a salinity intermediate water (halocline) at $25 \mathrm{~m}$ depth of the Sea of Marmara (2).

There is a rich body of literature on the biodiversity of the Sea of Marmara. However, the number of studies conducted on the Marmara Island is relatively small.
The first study at the island was carried out by Ostroumoff $(3,4)$ followed by studies by Okuş (5), Yüksek (6) and Balkıs (7).

\section{MATERIALS AND METHODS}

\section{Sample Collection}

Samplings were performed at the coastal waters of the Marmara Island in May and November months of 2008 year. Specimens of decapod crustaceans were captured from 12 sites at the depths between 0 and 60 $\mathrm{m}$. The sampling stations are shown in Figure 1. Samples were hand-picked or collected using a hand-held scoop while the offshore samples were collected using a beam trawl with a mesh size of $18 \mathrm{~mm}$. The samples were preserved in $5 \%$ formalin and species were stored in $70 \%$ ethanol .

\section{Sample Identification}

Specimens of decapoda were identified using the criteria as previously described by Bouvier (8), Zariquiey Alvarez $(9,10)$, Demir (11), Holthuis (12-15), Geldiay and Kocatas $(16,17)$, Ingle $(18,19)$ and Balkıs $(20)$. The names of the species were updated according to WORMS (21). 


\section{Measurements and Analysis}

During the study, sea water variables such as temperature, were measured in situ. The temperature was measured using the thermometer on the sampling flask. The salinity was measured using silver nitrate titration using the Mohr-Knudsen method (22). The amount of dissolved oxygen was measured using a sodium thiosulfate titration according to the Winkler method (23).

Soyer's (24) Frequency index (Fs) was used to determine the frequency of the decapod species in the coastal zones of the study field. The results were analysed in three groups according to calculated Fs values as 'constant' ( $F s \geq 50 \%)$, 'common' (50\% $>$ Fs $\geq 25 \%)$ and 'rare' (Fs $<25 \%)$. The Dominance Index Formula was used to determine the dominance of the decapod species in the coastal zones of the study field (25).

Bray-Curtis similarity index and (MDS) analyses were performed in the Primer v6 program to determine the similarity between

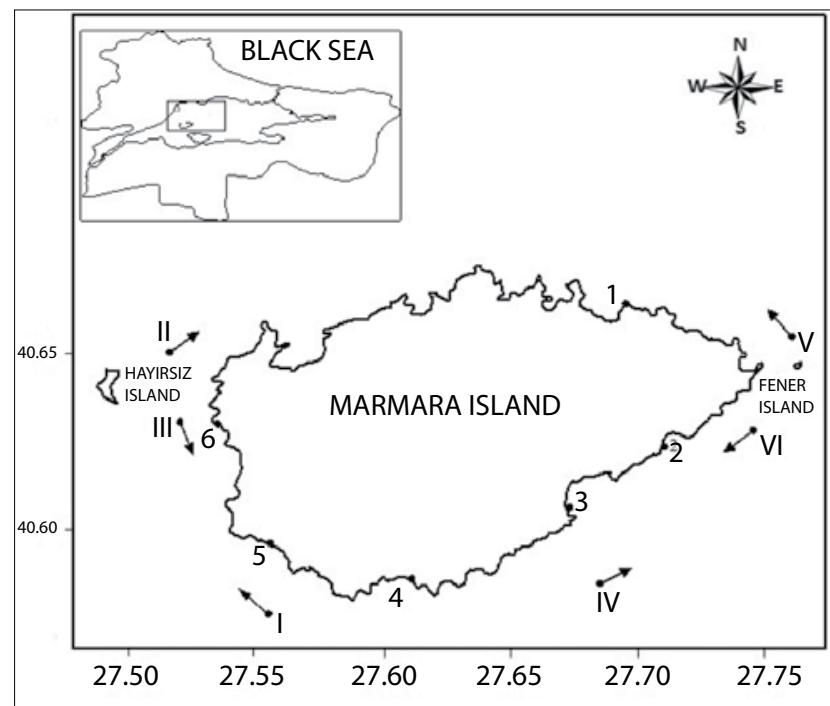

Figure 1. Map showing the sampling sites the sampled stations (26). For these analyses, firstly, log $(x+1)$ conversion was applied on raw information. Using the composition of the number of species and the number of individuals at the sampling stations Shannon-Weaver Diversity Index $\left(H^{\prime}\right)$ was performed.

\section{RESULTS}

\section{Environmental Variables}

The ecological variable such as temperature $\left({ }^{\circ} \mathrm{C}\right)$, salinity (\%o) and dissolved oxygen ( $\left.\mathrm{mg} \mathrm{L}^{-1}\right)$ at the sampling stations in the littoral zone of the Marmara Island were presented in Table 1.

The temperature varied between $14.3^{\circ} \mathrm{C}$ and $18.0^{\circ} \mathrm{C}$ in the two sampling periods. The temperature lowered with depth. The salinity values ranged from $21.2 \%$ o to $35.7 \%$. As a natural feature of the two-layered water system of the Sea of Marmara, the salinity increased with depth. The highest dissolved oxygen value (12.98 $\left.\mathrm{mg} \mathrm{l}^{-1}\right)$ was obtained in May from station 2 and the lowest value $\left(5.65 \mathrm{mg} \mathrm{l}^{-1}\right)$ was obtained in May from station $V$ at the depth of $50 \mathrm{~m}$.

\section{Faunistic Data}

A total of 17 species of decapod crustaceans were reported (Table 2). Table 2 shows 10 species out of 17 species found from the onshore sampling while 7 from the offshore sampling studies. Pink shrimp Parapenaeus longirostris, Majid crab Maja squinado and Portunid crab Liocarcinus depurator observed from the offshore were found at the depths of 40,50 and $60 \mathrm{~m}$, respectively. Pandalid shrimp Plesionika heterocarpus, Crangonid shrimp Aegaeon lacazei and Norway lobster Nephrops norvegicus were reported only at the depth of $60 \mathrm{~m}$, and brachyuran crab Dromia personata at the depth of $40 \mathrm{~m}$. No common species was detected both from the shore and the deep water.

A total of 10 species were obtained during the onshore sampling (Table 3). While the highest number of species was observed with 6 species at site 5 in May, the lowest value (2 species) was recorded at site 4 . In November, the highest number

Table 1. Coordinates of sampling stations on the Marmara Island and physicochemical data of seawater

\begin{tabular}{|c|c|c|c|c|c|c|c|}
\hline \multirow[b]{2}{*}{ Station } & \multirow[b]{2}{*}{ Depth (m) } & \multicolumn{3}{|c|}{ SPRING } & \multicolumn{3}{|c|}{ AUTUMN } \\
\hline & & $\begin{array}{c}\text { Temperature } \\
\left({ }^{\circ} \mathrm{C}\right)\end{array}$ & $\begin{array}{c}\text { Salinity } \\
(\% \circ)\end{array}$ & $\begin{array}{c}\text { Dissolved } \\
\text { Oxygen }\left(\mathrm{mg} \mathbf{l}^{-1}\right)\end{array}$ & $\begin{array}{c}\text { Temperature } \\
\left({ }^{\circ} \mathrm{C}\right)\end{array}$ & $\begin{array}{c}\text { Salinity } \\
(\% \circ)\end{array}$ & $\begin{array}{c}\text { Dissolved } \\
\text { Oxygen }\left(\mathrm{mg}^{-\mathrm{I}^{-1}}\right)\end{array}$ \\
\hline 1 & 0.5 & 18.0 & 21.3 & 11.54 & 15.0 & 24.2 & 10.43 \\
\hline 2 & 0.5 & 17.5 & 21.7 & 12.98 & 15.0 & 23.9 & 9.26 \\
\hline 3 & 0.5 & 17.5 & 21.2 & 10.63 & 14.9 & 23.7 & 9.44 \\
\hline 4 & 0.5 & 17.0 & 21.8 & 11.73 & 15.0 & 23.7 & 9.13 \\
\hline 5 & 0.5 & 17.0 & 21.3 & 11.89 & 15.1 & 24.4 & 9.97 \\
\hline 6 & 0.5 & 17.0 & 21.9 & 10.11 & 14.9 & 23.4 & 8.92 \\
\hline 1 & 50 & 14.5 & 35.3 & 6.97 & 16.9 & 35.7 & 10.18 \\
\hline II & 60 & 14.5 & 35.1 & 6.22 & 16.0 & 34.8 & 9.27 \\
\hline III & 40 & 14.5 & 35.6 & 6.28 & 16.2 & 35.1 & 8.25 \\
\hline IV & 60 & 14.3 & 35.0 & 6.26 & - & - & - \\
\hline V & 50 & 15.0 & 34.4 & 5.65 & - & - & - \\
\hline VI & 40 & 14.8 & 33.8 & 6.75 & - & - & - \\
\hline
\end{tabular}




\begin{tabular}{|c|c|c|c|c|}
\hline & \multicolumn{4}{|c|}{ Depths (m) } \\
\hline & $0-1$ & 40 & 50 & 60 \\
\hline \multicolumn{5}{|l|}{ Order DECAPODA } \\
\hline \multicolumn{5}{|l|}{ Suborder DENDROBRANCHIATA } \\
\hline Parapenaeus longirostris (Lucas, 1946) & & + & + & + \\
\hline \multicolumn{5}{|l|}{ Suborder PLEOCYEMATA } \\
\hline \multicolumn{5}{|l|}{ Infraorder CARIDEA } \\
\hline Aegaeon lacazei (Gourret, 1887) & & & & + \\
\hline Palaemon elegans Rathke, 1837 & + & & & \\
\hline Plesionika heterocarpus (A. Costa, 1871) & & & & + \\
\hline \multicolumn{5}{|l|}{ Infraorder ASTACIDEA } \\
\hline Nephrops norvegicus (Linnaeus, 1758) & & & & + \\
\hline \multicolumn{5}{|l|}{ Infraorder ANOMURA } \\
\hline Clibanarius erythropus (Latreille, 1818) & + & & & \\
\hline Diogenes pugilator (Roux, 1829) & + & & & \\
\hline Pisidia bluteli (Risso, 1816) & + & & & \\
\hline Pisidia longimana (Risso, 1816) & + & & & \\
\hline Porcellana platycheles (Pennant, 1777) & + & & & \\
\hline \multicolumn{5}{|l|}{ Infraorder BRACHYURA } \\
\hline Carcinus aestuarii Nardo, 1847 & + & & & \\
\hline Dromia personata (Linnaeus, 1758) & & + & & \\
\hline Liocarcinus depurator (Linnaeus, 1758) & & + & + & + \\
\hline Liocarcinus vernalis (Risso, 1827) & + & & & \\
\hline Maja squinado (Herbst, 1788) & & + & + & + \\
\hline Pilumnus hirtellus (Linnaeus, 1761) & + & & & \\
\hline Xantho poressa (Olivi, 1792) & + & & & \\
\hline
\end{tabular}

of species (6) was found at station 4 and the lowest (2 species) at station 1. Among these species found during offshore samplings, only brachyuran crab $X$. poress $a$ is constant species in both seasons. The common species in spring are Paguroid $D$. pugilator, Portunid crab C. aestuarii, Anomuran P. bluteli, and Paguroid C. erythropus. In autumn, P. bluteli and Pisidia longimana are constant species while C. erythropus, C. aestuariiand $P$. hirtellus are common species. Dominance index values show that, $D$. pugilator and $X$. poressa are dominant species in spring and in autumn, respectively.

A total of 7 decapod crustaceans were found at the offshore sampling stations (Table 4). In May and November, the highest number of species (4) was found at station II while the lowest (2) at station I. Out of these 7 species, A. lacazei was caught only in November while $N$. norvegicus and $D$. personata were found only in May. No samples could be collected at stations IV, V and $\mathrm{VI}$ in November. The general distribution of the species indicates that $P$. longirostris (429 individuals) and L. depurator (362 individuals) were collected from all the offshore sampling stations both in May and November.

$\left(H^{\prime}\right)$ values for grab samples collected from Marmara a Island are presented in Table 5. When $\left(H^{\prime}\right)$ values of the studied sites were analyzed, site 4 in autumn was found to have the highest $H^{\prime}$ value.

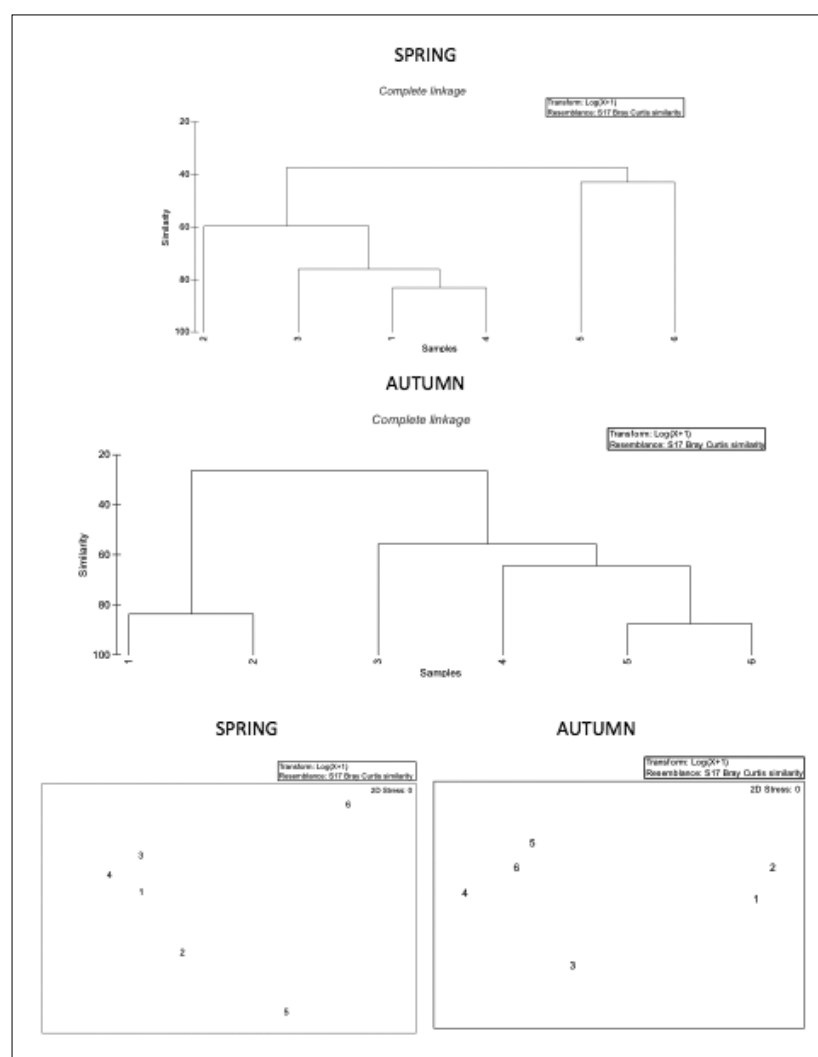

Figure 2. Bray-Curtis similarity index and similarity between stations according to MDS methods

The similarities between the stations were evaluated according to the distributions of the species obtained from the onshore sampling stations.

The results of the Bray-Curtis similarity index and MDS methods applied at the onshore sampling stations in the spring and autumn are shown in Figure 2.

Figure 2 shows that there is a similarity between stations 1, 4 and 3 in the spring, while there is a similarity between stations 1 and 2 , and between stations 5 and 6 in the autumn.5.

\section{DISCUSSION}

The zoogeographical characteristics of the species were presented according to d'Udekem d'Acoz (27) and in compliance with Števčić (28). Accordingly 12 species reported here (P. longirostris, $P$. heterocarpus, N. norvegicus, $P$. longimana, $P$. platycheles, $C$. erythropus, $D$. personata, C. aestuarii, $L$. depurator, $L$. vernalis, $X$. poressa and $P$. hirtellus) are Atlanto-Mediterranean originated, therefore, 3 species (P. elegans, A. lacazei and D. pugilator) are Cosmopolitan and the remaining two (P. bluteli and M. squinado) are Mediterranean Endemic.

Previous studies on the Turkish Strait System' decapods have examined the first records provided by Forskål (29) showing the presence of 2 crab species in Istanbul [Nepinnotheres 
Eur J Biol 2017; 76(1): 20-5

Ayfer et al. An Decapod Crustacea Species of the Marmara Island

\begin{tabular}{|c|c|c|c|c|c|c|c|c|c|c|c|c|c|c|c|c|}
\hline \multirow[b]{3}{*}{ Species } & \multicolumn{15}{|c|}{ Shore Stations } & \\
\hline & \multicolumn{6}{|c|}{ Spring } & \multicolumn{10}{|c|}{ Autumn } \\
\hline & 1 & 2 & 3 & 4 & 5 & 6 & $f \%$ & Di \% & 1 & 2 & 3 & 4 & 5 & 6 & $f \%$ & Di \% \\
\hline Palaemon elegans & & & & & & & 0 & 0 & & 1 & & & & & 16.6 & 0.89 \\
\hline Pisidia bluteli & & & & & 2 & 2 & 33.3 & 1.4 & & & 1 & 8 & 3 & 2 & 66.7 & 12.5 \\
\hline Pisidia longimana & & & & & & & 0 & 0 & & 2 & 1 & 4 & & 3 & 66.7 & 8.93 \\
\hline Porcellana platycheles & & & & & & 1 & 16.6 & 0.3 & & & & 8 & & & 16.6 & 7.14 \\
\hline Clibanarius erythropus & & & 2 & & 35 & & 33.3 & 13.1 & & & & 3 & 5 & & 33.3 & 7.14 \\
\hline Diogenes pugilator & 51 & 4 & 20 & 74 & 4 & & 83.3 & 54.26 & & & & & & & 0 & 0 \\
\hline Carcinus aestuarii & 2 & 3 & & & 5 & & 50 & 3.5 & 6 & 2 & & & & & 33.3 & 7.14 \\
\hline Liocarcinus vernalis & & & & & 1 & & 16.6 & 0.3 & & & & & & & 0 & 0 \\
\hline Xantho poressa & 17 & 5 & 11 & 6 & 27 & 10 & 100 & 26.95 & 7 & 5 & 8 & 13 & 10 & 18 & 100 & 54.46 \\
\hline Pilumnus hirtellus & & & & & & & & 0 & & & 1 & 1 & & & 33.3 & 1.79 \\
\hline
\end{tabular}

Table 4. List of decapod crustaceans collected using beam trawls

\begin{tabular}{|c|c|c|c|c|c|c|c|c|c|c|c|c|}
\hline \multirow[b]{3}{*}{ Species } & \multicolumn{12}{|c|}{ Beam Trawl Stations } \\
\hline & \multicolumn{6}{|c|}{ Spring } & \multicolumn{6}{|c|}{ Autumn } \\
\hline & $\mathbf{I}$ & II & III & IV & V & VI & $\mathbf{I}$ & II & III & IV & $\mathbf{V}$ & VI \\
\hline Parapenaeus longirostris & 21 & 74 & 49 & 71 & 28 & 54 & 33 & 61 & 37 & - & - & - \\
\hline Plesionika heterocarpus & 1 & & & 1 & & & 2 & & & & & \\
\hline Aegaeon lacazei & & & & & & & & 1 & & & & \\
\hline Nephrops norvegicus & & 1 & & & & & & & & & & \\
\hline Maja squinado & & & 2 & & 1 & & & & 1 & & & \\
\hline Dromia personata & & & & & & 1 & & & & & & \\
\hline Liocarcinus depurator & 19 & 3 & 16 & 47 & 3 & 101 & 57 & 65 & 51 & & & \\
\hline
\end{tabular}

Tablo 5. Shannon-Weaver Diversity Index $\left(H^{\prime}\right)$ values of the grab stations

\begin{tabular}{lcc}
\hline \multirow{2}{*}{ Stations } & \multicolumn{2}{c}{ H'Values $^{-}$} \\
\cline { 2 - 3 } & Spring & Autumn \\
\hline 1 & 0.2318 & 0.9957 \\
\hline 2 & 1.555 & 1.761 \\
\hline 4 & 1.2111 & 1.278 \\
\hline 5 & 0.3843 & 2.267 \\
\hline 6 & 1.757 & 1.415 \\
\hline
\end{tabular}

pinnotheres (Linnaeus 1758); Eriphia verrucosa (Forskål 1775)]. Then Bakır et al. (30) reported 144 and Balkıs et al. (31) reported a total of 140 decapod crustaceans from the area.

Researchers who previously studied on the Marmara Island and the species they identified are shown in Table 6.

Ostroumoff $(3,4)$ reported 14 species of decapod crustaceans in the littoral zone of the Marmara Island. Presence of the Liocarcinus holsatus is not very clear in this study so we accept the presence of 13 species as reported in the study. Okuş (5) reported the presence of 25 decapod Crustacea species in the littoral zone of the Marmara Island. However, 2 of these species were reported only at the level of genus and Liocarcinus depurator was specified twice in the study as Macropipus depurator and Liocarcinus depurator. Therefore, Okuş (5) reported 22 decapod species. Yüksek (6) reported the presence of 20 decapod species from the southern coasts of the Marmara Island. However, having reported 7 species only at the level of genus, she reported 13 decapod Crustacea species. Balkıs (7) carried out a study on the macrobenthos of the Marmara Island and reported 9 decapod species. Xantonid crab Xantho incicus and Caridean shrimp Hippolyte longirostris species reported by Balkıs were not found in the Sea of Marmara in previous studies. Therefore, presence of these species is not validated. Current literature indicates there are a total of 36 decapod crustaceans present in the littoral of the Marmara Island to the date.

The similarity percentage of the stations are so different in the spring and autumn as indicated by their similarity percentages. Many environmental factors, such as temperature and food, control zoogeographical distribution of decapod crustaceans (33). Algal vegetation increases in the spring and D.pugilator and $X$. poressa species are abundant living in algae to protect and feed themselves. Specimens hidden under the stone are more common in the autumn with limited vegetation.

Because samples obtained from the offshore sampling stations were collected using two beam trawls, the dominance, frequency and similarity indices were not calculated. The species identified onshore and offshore are completely different from each other which is thought to be due to the significant effect of depth and sediment type on the distribution of decapods (33). 


\begin{tabular}{|c|c|}
\hline \multicolumn{2}{|l|}{ Order DECAPODA } \\
\hline \multicolumn{2}{|l|}{ Suborder DENDROBRANCHIATA } \\
\hline Parapenaeus longirostris (Lucas, 1846) & 6, This study \\
\hline Penaeus kerathurus (Forskål, 1775) & 7 \\
\hline \multicolumn{2}{|l|}{ Suborder PLEOCYEMATA } \\
\hline \multicolumn{2}{|l|}{ Infraorder CARIDEA } \\
\hline Aegaeon lacazei (Gourret, 1887) & This study \\
\hline Alpheus glaber (Olivi, 1792) & 5 \\
\hline Athanas nitescens (Leach, 1813) & 5,7 \\
\hline Crangon crangon (Linnaeus, 1758) & 5 \\
\hline Hippolyte holthuisi Zariquiey Álvarez, 1953 & 5 \\
\hline Palaemon adspersus Rathke, 1837 & 5 \\
\hline Palaemon elegans Rathke, 1837 & $32,5,6$, This study \\
\hline Pandalina brevirostris (Rathke, 1843) & 5,7 \\
\hline Plesionika heterocarpus (A. Costa, 1871) & 32, This study \\
\hline Processa canaliculata Leach, 1815 & 5,6 \\
\hline Processa edulis edulis (Risso, 1816) & 32 \\
\hline Typton spongicola O.G. Costa, 1844 & 32 \\
\hline \multicolumn{2}{|l|}{ Infraorder ASTACIDEA } \\
\hline Homarus gammarus (Linnaeus, 1758) & 7 \\
\hline Nephrops norvegicus (Linnaeus, 1758) & This study \\
\hline \multicolumn{2}{|l|}{ Infraorder ANOMURA } \\
\hline Clibanarius erythropus (Latreille, 1818) & 5,This study \\
\hline Diogenes pugilator (Roux, 1829) & This study \\
\hline Galathea nexa Embleton, 1834 & 32 \\
\hline Galathea squamifera Leach, 1814 & 5 \\
\hline Munida rugosa (Fabricius, 1775) & 32 \\
\hline Pagurus cuanensis Bell, 1846 & 32 \\
\hline Pisidia bluteli (Risso, 1816) & This study \\
\hline Pisidia longicornis (Linnaeus, 1767) & 5,6 \\
\hline Pisidia longimana (Risso, 1816) & This study \\
\hline Porcellana platycheles (Pennant, 1777) & This study \\
\hline \multicolumn{2}{|l|}{ Infraorder BRACHYURA } \\
\hline Carcinus aestuarii Nardo, 1847 & $5,6,7$, This study \\
\hline Dromia personata (Linnaeus, 1758) & This study \\
\hline Ebalia cranchii Leach, 1817 & 32 \\
\hline Eriphia verrucosa (Forskål, 1775) & 5 \\
\hline Eurynome aspera (Pennant, 1777) & 32,5 \\
\hline Inachus leptochirus Leach, 1817 & 32 \\
\hline Inachus thoracicus Roux, 1830 & 6 \\
\hline Liocarcinus depurator (Linnaeus, 1758) & $32,5,6,7$, This study \\
\hline Liocarcinus navigator (Herbst, 1794) & $5,6,7$ \\
\hline Liocarcinus vernalis (Risso, 1827) & This study \\
\hline Macropodia longirostris (Fabricius, 1775) & 5,6 \\
\hline Macropodia rostrata (Linnaeus, 1761) & 5,6 \\
\hline Maja crispata Maja crispata Risso, 1827 & 5 \\
\hline Maja squinado (Herbst, 1788) & 5,6, This study \\
\hline Monodaeus couchii (Couch, 1851) & 32 \\
\hline Pilumnus hirtellus (Linnaeus, 1761) & 5,6, This study \\
\hline Pisa tetraodon (Pennant, 1777) & 32 \\
\hline Xantho poressa (Olivi, 1792) & 5, 6This study \\
\hline
\end{tabular}

Nine of the species ( $P$. longirostris; $P$. elegans, $P$. heterocarpus, $C$. erythropus, M. squinado, C. aestuarii, L. depurator, X. poressa and $P$. hirtellus) in this study have been reported before while the remaining 8 species (A. lacazei, N. norvegicus, P. bluteli, P. longimana, P. platycheles, D. pugilator, D. personata and $L$. vernalis) have been reported in the littoral zone of Marmara Island for the first time in this study. Including these species, the number of decapod Crustacea species found in the littoral zone of Marmara Island has increased to 44.

This study was conducted in spring and autumn and hence 8 more species have been added to the decapod crustaceans reported to be living in the littoral zone of Marmara Island. In addition, some ecological factors of the habitats of these species have been revealed. This study will also contribute to the further systematic and ecological studies on decapod crustaceans in the region.

\section{Acknowledgements}

This study was supported by (the Research Fund of Istanbul University (project number: 1389).

\section{REFERENCES}

1. Akyol O, Ceyhan T, Ertosluk O. Marmara Adasi Kiyi Balikciligi ve Balikcilik Kaynaklari. Ege J FAS 2009; 26(2): 143-48.

2. Besiktepe ST, Sur HI, Ozsoy E, Latif MA, Oguz T, Unluata U. The circulation and hidrography of the Marmara Sea. Prog Oceanogr 1995; 34(4): 285-334. [CrossRef]

3. Ostroumoff A. Further contributions to the natural history of the Bosphorus. Zapisok Imperatorskoy Akademii Nauk, St. Petersburg, Supplement 1894; 74(5): 1-46 (in Russian).

4. Ostroumoff A. Comptes-rendus des dragages et du plancton de l'expédition de "Selianik". Bulletin de l'Académie Impériale des Sciences de St.-Pétersbourg, série 5, 5: 33-92 (in Russian) 1896.

5. Okus E. Marmara Adasi (Kuzey) littoralinde yapılan arastirmalar. Istanbul Universitesi Deniz Bilimleri ve Cografya Enstitusu Bulteni 1989; 6: 143-66.

6. Yuksek A. Marmara Adası guney sahillerinin littoral biotasi uzerinde bir arastirma. Istanbul Universitesi Deniz Bilimleri ve Cografya Enstitusu Bulteni 1989; 6: 203-16.

7. Balkıs H. Marmara Adası littoralinin makrobentosu uzerine bir on arastirma. Istanbul Universitesi Deniz Bilimleri ve Cografya Enstitusu Bulteni 1992; 9: 309-27.

8. Bouvier EL. Decapodes Marcheurs, Faune de France, Editions Paul Lechevalier et fils, 12, Rue de Tournon (Vle), Paris, 37, 404 pp (1940).

9. Zariquiey Alvarez R. Crustáceos Decápodos Mediterráneos, Manual para la clasificacíon de las especies que pueden capturarse en las costas mediterráneas españolas (Publicaciones sobre Biología Mediterranánea II), Barcelona: Instituto Español de Estudios Mediterráneos 1946; 181 pp.

10. Zariquiey Alvarez R. Crustáceos Decápodos, Ibéricos Investigación Pesquera 1968; 32, 510 pp.

11. Demir M. Bogazlar ve Adalar Sahillerinin Omurgasiz Dip Hayvanlari, Istanbul Universitesi Fen Fakultesi Hidrobiyoloji Arastirma Enstitusu Yayinlarindan, Istanbul; 1952.

12. Holthuis LB. Report on a collection of Crustacea Decapoda and Stomatopoda from Turkey and the Balkans, Zoologische Verhandelingen 1961; 47: 1-67. 
13. Holthuis LB. Crevettes. In: Fischer W., M. Schneider, M.L. Bauchot, Fishes (Eds.) FAO d'identification des espéces pour les besoins de la peche, Mediterranée et mer noire, zone de péche 37, Végetaux et invertebres pp 189-292 FAO, Rome (1987a).

14. Holthuis LB. Homards, Langoustines, Langoustes et Cigales. In: Fischer W., M. Schneider, M.L. Bauchot (Eds.), Fishes FAO d'identification des espéces pour les besoins de la peche, Mediterranée et mer noire, zone de péche 37, Végetaux et invertebres Rome: 1987b. p.293-319.

15. Holthuis LB. (1987c) Vrais Crabes. In: Fischer W., M. Schneider, M.L. Bauchot (Eds.) Fishes FAO d'identification des espéces pour les besoins de la peche, Mediterranée et mer noire, zone de péche 37 , Végetaux et invertebres. Rome: 1987c.p.321-67.

16. Geldiay R, Kocataş A. İzmir Körfezi ve Civarında Tespit Edilen Natantia Türleri (Crustacea Decapoda), Ege Üniversitesi Matbaası, Bornova 1968; 51, $46 \mathrm{pp}$.

17. Geldiay R, Kocataş A. Türkiye'nin Ege Denizi Sahillerinden Tespit Edilen Anomurlar (Crustacea Decapoda) Hakkında, Ege Üniversitesi Matbaası, Bornova 1970.

18. Ingle JC. Cenozoic paleobathymetry and depositional history of selected sequences within the southern California continental bor- derland. Cushman Foundation for Foraminiferal Research, Special Publication 1980; 19:163-95.

19. Ingle R. Hermit crabs of the Northeastern Atlantic Ocean and Mediterranean Sea, An Illustrated key, Nat. Hist. Mus. Publ., Chapman and Hall, London: 1993.

20. Balkis H. Crabs in the Sea of Marmara. IUFS J Biol 1994; 57: 71-111.

21. WoRMS Editorial Board. World Register of Marine Species. Available from http://www.marinespecies.org at VLIZ. Accessed 201611-27. doi:10.14284/170 2016.

22. Ivanof A. Introduction a l'óceanographie, Tome I, Libraire Vuibert, Paris: 1972.

23. Winkler LW. The determination of dissolved oxgyen in water. Ber Deut Chem Ges 1888; 21:2843-55. [CrossRef]
24. Soyer T. Bionomie benthique du plateau continental de la cote catalane Française. III: Les peuplements de Copepodes Harpacticoides (Crustacea). Vie Millieu 1970; 21: 377-511.

25. Bellan-Santini D. Etude floristuque et faunistuque de quelques peuplements infralittoraux de substratrocheus. Rec Travaux de la Station Marine d'Endoume 1969; 26: 237-98.

26. Clarke KR, Warwick RM. A further biodiversity index applicable to species lists: variation in taxonomic distinctness. Mar Ecol Prog Ser 2001; 216: 265-78. [CrossRef]

27. Udekem d'Acoz CD.. Inventaire et Distribution des Crustaces Decapodes de I'Atlantique Nord-Oriental, de la Mediterranee et des Eaux Continentales Adjancentes au Nord de $25 \circ \mathrm{N}$. Patrimoines Naturels (Muséum National D'Histoire Naturelle Service Du Patrimoine Naturel), Bruxelles; 1999.

28. Števcıc Z. Check-list of the Adriatic Decapod Crustacea. Acta Adriatica 1990; 31: 183-274.

29. Forskål P. Descriptiones Animalium, Avium, Amphibiorum, Piscium, Insectorum, Vermium; quae in Itinere orientali observavit Petrus Forskål. Post Mortem Auctoris edidit Carsten Niebuhr. Adjuncta est materia medica Kahirina.Hafniae, 9: xxxiv, 164 pp., 1 map (in Latin): 1775.

30. Bakir AK, Katagan T, Aker HV, Ozcan T, Sezgin M, Ates AS, et al. The marine arthropods of Turkey", Turk J Zool 2014; 38(6): 765-831. [CrossRef]

31. Balkis H, Mulayim A, Karhan S. Crustacea Malacostraca in the Sea of Marmara: A Checklist. In E. Özsoy, M.N. Çağatay, N. Balkıs, N. Balkıs \& B. Öztürk (Eds.), In The Sea Of Marmara: Marine Biodiversity, Fisheries, Conservation And Governance, Tüdav, İstanbul, Turkey; 2016. p.468-502.

32. Muller GJ. Review of the hitherto recorded species of Crustacea Decapoda from the Bosphorus, the Sea of Marmara and the Dardanelles. Cercetari Marine, I. R. C. M. Constanta 1986; 19: 109-30.

33. Fanelli E, Colloca F, Ardizzone G. Decapod crustacean assemblages off the West coast of central Italy (western Mediterranean). Sci Mar 2007; 71: 19-28. [CrossRef] 